\title{
Jeanette Little Scholarship Scheme Recipient Report: Developments in Pacific Libraries and Issues Faced
}

\author{
by Jackson Ray
}

$\mathrm{L}$ ibraries in the Pacific have come a long way within the last two decades. There have been drastic changes to the way libraries operate and there are always the opposite. By that I mean, there are libraries that have changed with the flow and have jumped on to the technology bandwagon; whilst a lot more libraries are still back in the old sack (i.e. doing things as usual as has been done).

I can only speak of what I experience and see

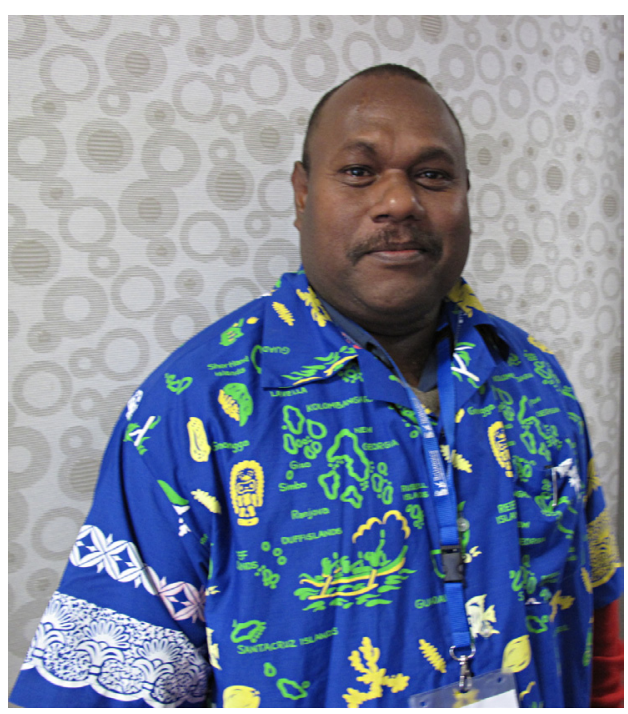
in my country but, I believe, this is likely to be the same in other Pacific Island countries as well.

\section{Qualification}

On the positive side, pursuing a career in librarianship is within reach as library courses are readily offered by certain institutions in the Pacific, namely the University of the South Pacific (USP), the University of Papua New Guinea (UPNG) and Fiji National University (FNU). Whilst the first two offer diplomas, within the last two years FNU is offering a BA in librarianship. This means that for the serious librarians, qualification is a sure thing so long as funding is assured. This, however, is the major obstacle facing librarians in Solomon Islands.

I can confidently say that as far as holding a degree in librarianship is concerned, only one, if not none, of us has it. Most of the librarians we have are diploma graduates. This was due to the fact that a degree was not offered in the two major regional institutions (USP and UPNG). It is possible now.

\section{Status}

At least a librarian is better paid than a teacher in my country. As a technical field, librarians are less vulnerable to redundancies and terminations. This was my experience working at the National Library for the most part of my employment. Other officers of other ministries were affected during much of the government's restructuring, but not one librarian was affected. 


\section{"People rarely}

\section{consider}

librarianship as a

profession and those

taking it are either

job opportunists

or those wanting

\section{to gain some}

experience, only to

be found leaving it

when opportunity

and greener pastures

are available."
In my current position as librarian of a college, I am included as a member of the faculty. Something I didn't have when I looked after the same library in 2003. Currently I am paid at the level of Lecturer 1 which again was not the case in 2003. So I believe there is some recognition but not as fully as we expect.

\section{Technology}

This is one area that has revolutionized the way libraries operate in the last five to ten years, at least in Solomon Islands. A few libraries have managed to automate their library collections. This is due to the fact that technology itself is relatively new to us; only becoming more relevant and necessary after 2000 when we saw the trend where the world was heading.

Those who managed to have access to technology have people trained not only on library software, but on Information and Communications Technology (ICT) as well. They have bigger budgets which enable them to train their personnel and acquire the technology.

It may still be a long way before most of the libraries would be able to acquire the technology and the know-how to run the programs.

\section{Not So Positive Side}

On the negative side of library development, there is a trend that people often overlook this profession. It is usually the case that people often look to occupations that are more common, such as medical doctors, business, technology and the arts.

People rarely consider librarianship as a profession and those taking it are either job opportunists or those wanting to gain some experience, only to be found leaving it when opportunity and greener pastures are available. This is true in Solomon Islands. Eventually, you will find only women staying on as librarians rather than their male colleagues.

\section{Illiteracy}

This is a huge problem in most countries in the Pacific. It is interesting, because it is reflected even in the tertiary level. 